\section{Deterioration of Three Potentially Biodegradable Plastic Mulches Before and After Soil Incorporation in a Broccoli Field Production System in Northwestern Washington}

\author{
Jeremy S. Cowan ${ }^{1,4,7}$, Debra A. Inglis ${ }^{2,5}$, and Carol A. Miles ${ }^{3,6}$
}

ADDITIONAL INDEX WORDs. certified organic, degradation, mulch fragments

Summary. Three potentially biodegradable plastic mulch products, Mater-bi ${ }^{\circledR}$ based black film (BioAgri), experimental polyhydroxyalkanoate film (Crown 1), and experimental spunbonded polylactic acid fabric (SB-PLA-11), were evaluated over two broccoli (Brassica olevacea var. italica) growing seasons to determine deterioration before and after soil incorporation. Pretillage mulch deterioration was evaluated in both growing seasons by rating the percent visual deterioration (PVD). Crown 1 had the greatest PVD throughout the study $(P \leq 0.05)$ and BioAgri also had significant pretillage deterioration. SB-PLA-11 showed no appreciable deterioration based on PVD $(<1.3 \%)$ in either growing season. Postincorporation mulch deterioration was measured for 13 months after rototilling at the end of the first growing season. The average fragment area of all mulch products decreased over time after soil incorporation. The number of postincorporation mulch fragments initially increased for all mulch products, with Crown 1 and BioAgri reaching maximum fragment counts 132 and 299 days after incorporation, respectively. As the number of fragments declined, the average area of fragments did not change, suggesting that a threshold fragment size may exist at which biodegradation accelerates. At the end of the study period, 397 days after soil incorporation, Crown 1 and BioAgri had deteriorated $100 \%$ and $65 \%$, respectively; whereas SB-PLA-11 showed very little deterioration.

$\mathrm{P}$ olyethylene plastic mulch has become a standard production input for specialty crop growers seeking enhanced yields, fewer days to harvest, reduced weed competition, and more efficient use of water and fertilizers, among other benefits (Lamont, 2005). In 2006, $\approx 160,000$ ha of agricultural land in the United States were covered with plastic mulch (Miles et al., 2012). However,

Funding for this project was provided by NIFA SCRI SREP for "Biodegradable Mulches for Specialty Crops Produced Under Protective Covers" (Award No. 2009-51181-05897)

Internal review by Steven $\mathrm{S}$. Jones and Thomas $\mathrm{L}$. Marsh and the technical assistance of Jonathan Roozen and Steve Moses is gratefully acknowledged.

${ }^{1}$ Washington State University, Northwestern Washington Research and Extension Center, 16650 SR 536, Mount Vernon, WA 98273

${ }^{2}$ Department of Plant Pathology, Washington State University, Northwestern Washington Research and Extension Center, 16650 SR 536, Mount Vernon, WA 98273

${ }^{3}$ Department of Horticulture, Washington State University, Northwestern Washington Research and Extension Center, 16650 SR 536, Mount Vernon, WA 98273

${ }^{4}$ Postdoctoral Research Assistant

${ }^{5}$ Professor

${ }^{6}$ Associate Professor

${ }^{7}$ Corresponding author. E-mail: jeremy.cowan@wsu.edu. polyethylene plastic mulch is typically only used for one cropping season, after which it must be removed from the field and disposed of, at a cost of up to $\$ 250 /$ ha (Shogren and Hochmuth, 2004). Although recycling facilities exist in some parts of the United States, the difficulty and relatively high cost of recycling drive many growers to landfill their spent plastics (Garthe and Kowal, 1993; Olsen and Gounder, 2001; Shogren, 2000). Despite these options, some growers choose to bury or burn plastic mulches on-site (Shogren and Hochmuth, 2004), which has serious environmental consequences.

There is a growing interest in biodegradable plastics as an alternative to polyethylene for agricultural mulch. Biodegradable plastics are a class of plastic materials which degrade due to the action of naturally occurring microorganisms such as bacteria, fungi, and algae (ASTM International, 2011a). There have been numerous field studies investigating the effects of biodegradable plastic mulch on yield and crop quality (Arméndariz et al., 2006; Candido et al., 2003; Martín-Closas et al., 2008; Miles et al., 2012; Moreno et al., 2009; Olsen and Gounder, 2001; Rangarajan and Ingall, 2006), efficacy for weed suppression (Anzalone et al., 2010; Jenni et al., 2004; Minuto et al., 2008), and functional performance and degradability (Briassoulis, 2006; Cascone et al., 2008; Kapanen et al., 2008; Kijchavengkul et al., 2008; Ngouajio et al., 2008; Scarascia-Mugnozza et al., 2006; Tocchetto et al., 2001). These studies have shown that biodegradable plastic mulch can perform comparably to polyethylene mulch in crop yield and quality, weed suppression, and overall function. Most of these studies report satisfactory deterioration of biodegradable plastic mulch both in-season and postharvest. Nevertheless, reported deterioration varies depending on mulch material tested, cropping system, and climate.

Despite the positive results of scientific research, the successful transition from nondegradable plastic mulch to biodegradable plastic mulch use in agriculture, ultimately, will be grower driven. According to Miles et al. (2009), growers indicate they lack

\begin{tabular}{llll}
\hline $\begin{array}{l}\text { Units } \\
\text { To convert U.S. to } \\
\text { SI, multiply by }\end{array}$ & U.S. unit & SI unit & $\begin{array}{l}\text { To convert SI to } \\
\text { U.S., multiply by }\end{array}$ \\
\hline 0.4047 & $\mathrm{acre}(\mathrm{s})$ & $\mathrm{ha}$ & 2.4711 \\
29.5735 & $\mathrm{fl} \mathrm{oz}$ & $\mathrm{mL}$ & 0.0338 \\
0.3048 & $\mathrm{ft}$ & $\mathrm{m}$ & 3.2808 \\
0.0929 & $\mathrm{ft}^{2}$ & $\mathrm{~m}^{2}$ & 10.7639 \\
3.7854 & $\mathrm{gal}$ & $\mathrm{L}$ & 0.2642 \\
2.54 & inch(es) & $\mathrm{cm}$ & 0.3937 \\
25.4 & inch(es) & $\mathrm{mm}$ & 0.0394 \\
6.4516 & inch & $\mathrm{cm}$ & 0.1550 \\
16.3871 & inch & $\mathrm{cm}$ & 0.0610 \\
1.1209 & lb/acre & $\mathrm{kg} \cdot \mathrm{ha}^{-1}$ & 0.8922 \\
0.0254 & $\mathrm{mil}$ & $\mathrm{mm}$ & 39.3701 \\
1.6093 & $\mathrm{mph}$ & $\mathrm{km} \cdot \mathrm{h}^{-1}$ & 0.6214 \\
2.2417 & ton $/ \mathrm{acre}$ & $\mathrm{Mg} \cdot \mathrm{ha}^{-1}$ & 0.4461 \\
10.7639 & $\mathrm{~W} / \mathrm{ft}^{2}$ & $\mathrm{~W} \cdot \mathrm{m}^{-2}$ & 0.0929 \\
$\left({ }^{\circ} \mathrm{F}-32\right) \div 1.8$ & ${ }^{\circ} \mathrm{F}$ & ${ }^{\circ} \mathrm{C}$ & $\left({ }^{\circ} \mathrm{C} \times 1.8\right)+32$ \\
& & &
\end{tabular}

Hortlechnology • December 2013 23(6) 
sufficient information to evaluate the efficacy of biodegradable plastic mulches or understand the potential impacts on soil health and quality. During focus group meetings in 2012, participants in northwestern Washington expressed their concern about the accumulation of nondegraded mulch fragments in the soil and the impact on soil quality (Cowan, 2013). Producers of certified organic crops are particularly concerned about these issues. Although not yet permitted by the National Organic Program, in Oct. 2012 the National Organics Standards Board (NOSB) recommended that biodegradable plastic mulch be allowed in certified organic systems if it deteriorates $90 \%$ within 2 years (NOSB, 2012). The recommendation also puts responsibility on growers to demonstrate during the inspection process and certification review that "biodegradation of the mulch film is occurring so that it does not accumulate in the fields where it is used" (NOSB, 2012). Although laboratory methods exist to determine biodegradability of plastics in soil [ASTM 5998-03 (ASTM International, 2003) and ASTM WK 29802 (ASTM International, 2011b)], growers do not have any readily available tools to evaluate biodegradation in the field.

There are few studies that evaluate the fate of biodegradable plastic mulch after being incorporated into the soil postharvest. Calmon et al. (1999) introduced a photographic method to evaluate the deterioration of biodegradable plastic films buried in soil. However, this study did not use biodegradable plastic mulch, and the films were not first subjected to field conditions within a cropping system nor incorporated using typical tillage methods. Briassoulis (2007) reported using Calmon's method to evaluate biodegradable plastic mulch under irrigated field conditions; however, these samples were not incorporated using typical tillage and it is not clear whether buried samples were first exposed to field conditions during a crop season. A study in Italy reported rototilling biodegradable plastic mulch into the soil after field exposure throughout a tomato cropping season and evaluating sieved mulch fragments by weight $14 \mathrm{~d}$ postincorporation (Minuto et al., 2008). Also, Kapanen et al. (2008) reported on evaluating postincorporation deterioration by weight after sieving soil samples through a $1.8-\mathrm{cm}$ screen on the day of incorporation, and 1,3 , and 12 months after incorporation following a strawberry crop in the field. All of the aforementioned studies concluded that the buried films under evaluation deteriorated in the soil. Other studies report measuring postincorporation deterioration of biodegradable plastic mulch under field conditions; however, postincorporation methods or results are not fully presented (Kijchavengkul et al., 2008; Moreno and Moreno, 2008).

To address the need for growers to assess the biodegradability of mulch in the soil, research studies must focus on developing tools that growers can use to monitor deterioration both during and after cropping. The objective of this study was to evaluate three biodegradable plastic mulch products using subjective visual assessments of deterioration during the cropping season and a photographic method to monitor deterioration after the mulches were incorporated into the soil.

\section{Materials and methods}

This study was conducted at Washington State University (WSU)
Northwestern Washington Research and Extension Center at Mount Vernon, WA, during the 2011 and 2012 growing seasons. The field site was managed organically throughout the study as well as the 2 years prior. The soil type at the field site is Skagit silt loam, classified as a fine-silty, mixed, nonacid, mesic Typic Fluvaquent recently formed of alluvium and volcanic ash [U.S. Department of Agriculture (USDA), 2013]. Skagit silt loam, a very dark silt loam to $30 \mathrm{~cm}$ deep, overlays layers of silty loam, silty clay loam, and very fine sandy loam (USDA, 2013). Average temperature during the summer is $14.1^{\circ} \mathrm{C}\left(19.7 / 8.7^{\circ} \mathrm{C}\right.$ average maximum/minimum), and average temperature during the winter is $7.3{ }^{\circ} \mathrm{C}\left(11.3 / 3.3^{\circ} \mathrm{C}\right.$ average maximum/minimum) [National Climatic Data Center (NCDC), 2013]. Average total rainfall is $241 \mathrm{~mm}$ during the summer and $559 \mathrm{~mm}$ during the winter (NCDC, 2013). The area has a high water table, usually $76-91 \mathrm{~cm}$ below the surface, during the growing season (Klungland and McArthur, 1989).

Experimental Design. The experiment used a split-plot randomized complete block design with four replications. The whole-plot treatments were randomized and consisted of three biodegradable mulch products: BioAgri, Crown 1, and SB-PLA-11 (Table 1). Two subplot soil treatments, mulched and bare ground, were applied in the 2012 growing season over one half of each whole plot where mulch was incorporated into the soil previously.

BED PREPARATION AND MULCH TREATMENTS. On 5 July 2011 , six rows $124 \mathrm{ft}$ long and $2.5 \mathrm{ft}$ wide and spaced $6 \mathrm{ft}$ on center were prepared by rototilling, chisel plowing, and making two final passes with a rototiller before mulch laying; beds were flat with

Table 1. Biodegradable mulch products evaluated in broccoli field production at Mount Vernon, WA, in 2011 and 2012.

\begin{tabular}{|c|c|c|c|c|}
\hline Mulch product & Manufacturer & Mulch composition & $\begin{array}{l}\text { Thickness } \\
(\text { mil })^{\mathrm{z}}\end{array}$ & $\begin{array}{l}\text { Roll width } \\
\text { (inches) }^{\mathrm{z}}\end{array}$ \\
\hline BioAgri ${ }^{\circledR} \mathrm{Ag}$-Film & BIOgroupUSA, Palm Harbor, FL & $\begin{array}{l}\text { Cornstarch and nondisclosed biopolymers; } \\
\text { biodegradable and compostable; black }\end{array}$ & 0.6 & 48 \\
\hline Crown 1 & Crown Films, Burlington, WA & $\begin{array}{l}\text { Experimental polyhydroxyalkanoate film; } \\
\text { biodegradable and compostable; black }\end{array}$ & 1.0 & $47^{y}$ \\
\hline SB-PLA-11 & $\begin{array}{l}\text { Feedstock from NatureWorks, Blair, } \\
\text { NE; fabricated by Saxony Textiles, } \\
\text { Chemnitz, Germany }\end{array}$ & $\begin{array}{l}\text { Experimental nonwoven spunbond, } \\
\text { translucent, } 100 \% \text { polylactic acid; black }\end{array}$ & $22.83^{\mathrm{x}}$ & 43 \\
\hline
\end{tabular}

\footnotetext{
${ }^{\mathrm{z}} \mathrm{l} \mathrm{mil}=0.0254 \mathrm{~mm}, \mathrm{l}$ inch $=2.54 \mathrm{~cm}$.

${ }^{y}$ Crown 1 film was folded in half on the roll and had an overall width of 47 inches.

${ }^{x}$ SB-PLA- 11 had an average fiber diameter of $0.016 \mathrm{~mm} ; 1 \mathrm{~mm}=0.0394$ inch.
} 
opened furrows along both sides to accommodate mulch installation. An $8 \mathrm{ft}$ in-row buffer covered with black polyethylene mulch (Berry Plastics, Evansville, IN) separated whole plots. Fertilizer at the rate of $80 \mathrm{lb} /$ acre nitrogen [Par-4 (9N-1.3P-5.8K); North Pacific Ag Products, Clackamas, OR] and lime at a rate of 2.2 tons/acre (MICRONA Agricultural Gardening Lime; Columbia River Carbonates, Woodland, WA) were broadcast over the bed centers and incorporated before installing mulch. Drip tape [low flow, 0.6 inch diameter, 8 mils wall thickness, 8 inches emitter spacing (T-Tape 508-8-340; Deere \& Co., Moline, IL)] was centered on the bed beneath mulch treatments. Mulches were then laid over the drip tape the entire length of each whole plot. Whole plots measured $58 \mathrm{ft}$ long and $2.5 \mathrm{ft}$ wide. Mulches were laid by hand; each edge was placed in a furrow and covered with soil to secure it in the bed. In each whole plot, 28 transplant holes of 3 inches diameter were cut $2 \mathrm{ft}$ on center using a bulb digger (Ames True Temper, Camp Hill, PA).

On 29 Sept. 2011, the remaining mulch in each whole plot was incorporated to a depth of 6 inches by rototilling with two passes of the tractor. After the mulch in each whole plot was incorporated, the rototiller tines were inspected and any mulch found on the tines was removed, spread evenly across the whole plot, and turned in to the soil with a spade. Nine months later on 26 July 2012, each whole plot was prepared by rototilling with one pass of the tractor, then fertilizer at the rate of $80 \mathrm{lb} /$ acre $\mathrm{N}$ and lime at a rate of 2.2 tons/acre were broadcast over the bed centers and incorporated with a second pass of rototilling. Any mulch found on the rototiller tines was removed and spread evenly across the whole plot. Drip tape was centered on the bed and the same mulch products previously tilled into each whole plot were laid again, but this time over one-half of each whole plot to create mulched and bare ground subplots. Mulched subplots were laid by hand and punched with transplanting holes as described above.

ENVIRONMENTAL MONITORING. Environmental conditions were monitored using the WSU AgWeatherNet weather station located $1540 \mathrm{ft}$ from the study plots. Air temperature (Celsius), soil temperature (Celsius), relative humidity (percent), wind speed (kilometers per hour), incident solar radiation (watts per square meter), and cumulative precipitation ( $\mathrm{mm}$ ) were recorded every $15 \mathrm{~min}$. Growing degree days [base $5^{\circ} \mathrm{C}\left(\mathrm{GDD}_{5}\right)$ ] were calculated from the daily minimum $\left(T_{\min }\right)$ and maximum $\left(T_{\max }\right)$ temperatures according to the following formula:

$\mathrm{GDD}_{5}=\sum \max \left[\left(T_{\max }+T_{\min }\right) / 2-5,0\right]$

where $\left(T_{\max }+T_{\min }\right) / 2-5$ represents the differential between the average daily temperature and $5^{\circ} \mathrm{C}$, and the max function removes values less than zero. In 2011, the average soil temperature was measured and recorded every 15 min beneath each mulch in one repetition from 5 Aug. until 22 Sept. using a data logger (Hoboware H21-002; Onset Computer Corp., Bourne, MA). Soil temperature probes were installed 2 inches below the soil surface, in the center of the bed, $5 \mathrm{ft}$ from the northern-most end of each mulched plot.

Planting and maintenance. 'Castle Dome' broccoli (Osborne Seed Co., Mount Vernon, WA) was grown in this study as a late summer-fall crop. Plants were started from seed in the greenhouse on 3 June 2011 and 18 June 2012. Seeds were planted in potting mix (Sunshine Growers Natural \& Organic; Sun Gro Horticulture, Bellevue, WA) in standard 72cell greenhouse trays, and watering was done 5-6 d per week to keep the media damp. Seedlings were moved outside to harden-off in a well-ventilated hoop house on 29 June 2011 and 17 July 2012. Plants were watered every second day. Broccoli seedlings were transplanted to field plots on 6 July 2011 and 26 July 2012.

In 2011 , plants in the field were irrigated twice per week with 0.25 inch of water per application from transplanting until the end of the growing season. Liquid fertilizer [Converted Organics 521 (4.5N-0.9P-0.8K); Converted Organics of California, Gonzales, CA] was applied through fertigation every $10 \mathrm{~d}$, beginning at the time of transplanting, at a rate of $1 \mathrm{lb} /$ acre $\mathrm{N}$ per day. In 2012, plants were irrigated four times per week with 0.1 inches of water per application from transplanting until the end of the growing season. Liquid fertilizer was applied through fertigation every $7 \mathrm{~d}$, beginning at the time of transplanting, at a rate of $5 \mathrm{lb} /$ acre $\mathrm{N}$. Weeds were not removed within the mulched subplots; however, weeds growing in bare ground subplots and along mulch edges were removed by hand throughout the growing season consistent with commercial growers' management of mulched broccoli. Alleys between rows were maintained weed free by periodic rototilling and hand weeding. On 10 Aug. 2011 and 24 Aug. 2012, pyrethrin (Pyganic E.C. 5.0 II; MGK, Minneapolis, MN) was applied using a backpack sprayer (CP3; CooperPegler and Co., Burgess Hill, United Kingdom) at a rate of $5 \mathrm{~mL} / \mathrm{gal}$ to control cabbage aphid (Brevicoryne brassicae).

IN-SEASON VISUAL ASSESSMENTS. Visual assessments were performed on each mulched subplot to evaluate visible signs of deterioration. The evaluation area comprised the full width of the mulch from the planting hole at plant no. 1 to the planting hole at plant no. 4 , an area of $15 \mathrm{ft}^{2}$. In 2011 and 2012, an estimation of percent visual deterioration was recorded for each subplot twice monthly following Miles et al. (2012). PVD was estimated as the percent of soil exposed within the bounds of the evaluation section such that $0 \%=$ intact sample and $100 \%=$ completely degraded sample (not visible). PVD was recorded in $1 \%$ increments from $0 \%$ to $20 \%$, and in $5 \%$ increments thereafter. In 2011 and 2012 , the aggregate area under the mulch deterioration curve (AUMDC) was calculated from PVD values according to the following formula:

$$
\begin{aligned}
\operatorname{AUMDC}= & \sum_{t=0}^{n}\left(t_{n}-t_{n-1}\right) \\
& \times\left(\frac{\left|\mathrm{PVD}_{n}-\mathrm{PVD}_{n-1}\right|}{2}\right. \\
& \left.+\min \left(\mathrm{PVD}_{n}, \mathrm{PVD}_{n-1}\right)\right)
\end{aligned}
$$

where $t=$ number of days after mulch laying at measurement $n$, and the function min $\left(\mathrm{PVD}_{n}, \mathrm{PVD}_{(n-1)}\right)$ represents the lesser of the values of PVD at times $n$ and $n-1$. Mulch intactness was calculated as $100 \%$ minus PVD. 
Visual assessments were performed twice monthly during each cropping season from 15 July to 29 Sept. 2011 , and from 3 Aug. to 1 Nov. 2012. Photos were taken at each visual assessment.

Postincorporation MULCh SAMPLING. On 10 Nov. 2011, 8 Feb., 9 May, 24 July, and 30 Oct. 2012 (42, $132,223,299$, and $397 \mathrm{~d}$ after incorporation, respectively), soil samples were collected from each subplot to evaluate mulch deterioration postincorporation. At each sampling time, three cylindrical soil subsamples, each measuring 4 inches diameter and 6 inches deep, were extracted from each subplot and combined for a total volume of 226.2 inch $^{3}$, with a theoretical maximum mulch area of $37.5 \mathrm{inch}^{2}$ per sample. The theoretical maximum mulch area represents the combined area of the soil surface above each sample which would have been covered with mulch before soil incorporation. Subsample locations were randomized to eliminate sampling bias. Soil samples were wet sieved through a series of screens to $1.18 \mathrm{~mm}$ to extract mulch fragments. Extracted mulch fragments were stored in sealed plastic bags for not more than $72 \mathrm{~h}$ at $4{ }^{\circ} \mathrm{C}$. Fragments were cleaned by gentle agitation in water, laid out on a 15 -inch-square glass plate, and blotted dry.

IMAGE CAPTURE AND ANALYSIS. Each plated mulch sample was illuminated from above and below and photographed using a digital singlelens reflex camera (EOS Digital Rebel xT; Canon USA, Lake Success, NY) with an 18-55 mm lens (EFS 18-55, Canon USA) mounted 14 inches above the sample. Images were captured with aperture at $\mathrm{f} / 4.5$, focal length of $18 \mathrm{~mm}$, automatic white balance, ISO50 , and $1 / 50 \mathrm{~s}$ exposure. Images were $3456 \times 2304$ pixels and digitally saved using sRGB color representation. Lens distortion (pincushion), measured at $0 \%$ to $1.3 \%$, was identical for all images and was not corrected for image analysis.

Images were analyzed using Image J software (Rasband, 1997). The scale for each image was set by drawing a line between two points, $250 \mathrm{~mm}$ apart, and using the software's Set Scale function. Images were then converted to black and white, using ImageJ's default thresholding algorithms, and the colors inverted to make the mulch fragments black against a white background. Mulch fragments were analyzed using the Analyze Particles function with size $\geq 1 \mathrm{~mm}$ and circularity $=0.00-1.00$. A numbered outline drawing and results list, including the area and shape characteristics of each particle, were produced and saved. The original image was then compared with the numbered outline to verify that all outlined particles were, in fact, mulch fragments; any nonmulch particles were deleted from the results list. The number and the mean and total area of mulch fragments for each sample were calculated and recorded. The percent mulch recovered was calculated by dividing the total area of mulch fragments for each sample by the theoretical maximum mulch area, and percent postincorporation degradation was calculated by subtracting the percent mulch recovered from $100 \%$.

Statistical analysis. All data were subjected to analysis of variance using PROC MIXED in SAS (version 9.2 for Windows; SAS Institute, Cary, $\mathrm{NC})$. In-season visual assessment data were analyzed as a randomized complete block with repeated measures. Image analysis data were analyzed as a randomized complete block splitplot design with repeated measures. The MMAOV macro (Saxton, 2010) in SAS was used to build all PROC MIXED procedures using the Kenward and Roger (1997) method to determine denominator $\mathrm{df}$ for $\mathrm{F}$ tests and the autoregressive $[\operatorname{ar}(1)]$ correlation for repeated measures. Treatment means were compared for significant differences using Fisher's least significant difference test at alpha level of 0.05 . Although significant interactions were detected between main effects, treatments were analyzed separately. Some data were transformed before analysis to meet the assumptions of normality and homogeneity of variance; the most appropriate transformation was selected using the range method described by Kirk (1982). If no transformation satisfied the assumptions of normality or homogeneity of variance, a nonparametric analysis of variance was performed as described above after converting data into ranks using PROC RANK in SAS.

\section{Results}

ENVIRONMENTAL CONDITIONS. Overall climatic conditions were similar in both years of the study (Fig. 1;
Table 2;). The time from mulch laying until final harvest defined the cropping season each year in this study, and was $3 \mathrm{~d}$ longer in 2012 than in 2011. The later planting date in 2012 resulted in a decrease of $1.6^{\circ} \mathrm{C}$ in the average air temperature throughout the study period, the average daily minimum and maximum temperatures were 1.3 and $2.1^{\circ} \mathrm{C}$ lower, respectively, and there was a $14 \%$ reduction in $\mathrm{GDD}_{5}$ as compared with 2011. Similarly, the average soil temperature in bare ground subplots at 2 inches depth was $1.2{ }^{\circ} \mathrm{C}$ lower, the average daily solar photosynthetically active radiation was $11.3 \%$ lower, and the average relative humidity was $3.2 \%$ higher in 2012 than in 2011 . Average wind speed during the 2012 cropping season was $0.5 \mathrm{~km} \cdot \mathrm{h}^{-1}$ slower and total rainfall was $3.5 \mathrm{~mm}$ less than in 2011. In 2011, the soil temperature in mulched plots at 2inch depth beneath BioAgri and Crown I was equal to or slightly greater than bare soil, whereas soil temperature beneath SB-PLA-11 was $0.4{ }^{\circ} \mathrm{C}$ lower than bare soil.

P R E T I L L A g E M U L C H DETERIORATION. In 2011 and 2012, PVD differed by days after transplanting $[\mathrm{DAT}(P<0.0001$ both years $)]$ and mulch product $(P<0.0001$ both years), and there were significant interactions between product and DAT $(P=0.0004$ and $P=0.0002$, respectively). Thus, PVD data are presented separately by DAT. The PVD was two times greater for Crown 1 than for BioAgri by 27 DAT (1 Aug.) in 2011 and 67 DAT (1 Oct.) in 2012 (Fig. $2)$. In 2011, with the exception of the first assessment when Crown 1 and BioAgri were statistically equivalent, Crown 1 had the highest PVD throughout the growing season. SB-PLA-11 tended to have the lowest PVD; however, it was not statistically different from BioAgri 42 and 59 DAT (16 Aug. and 2 Sept., respectively). At the final assessment, PVD for SB-PLA-11 was nine times lower than that for BioAgri and 50 times lower than that for Crown 1. In 2012, PVD of BioAgri and Crown 1 were statistically equivalent through $50 \mathrm{DAT}$ (14 Sept.). From 67 DAT (1 Oct.) until the end of the growing season, PVD of Crown 1 was more than six times greater, on average, than BioAgri. PVD of SBPLA-11 was lower than for BioAgri and Crown 1 throughout the growing 


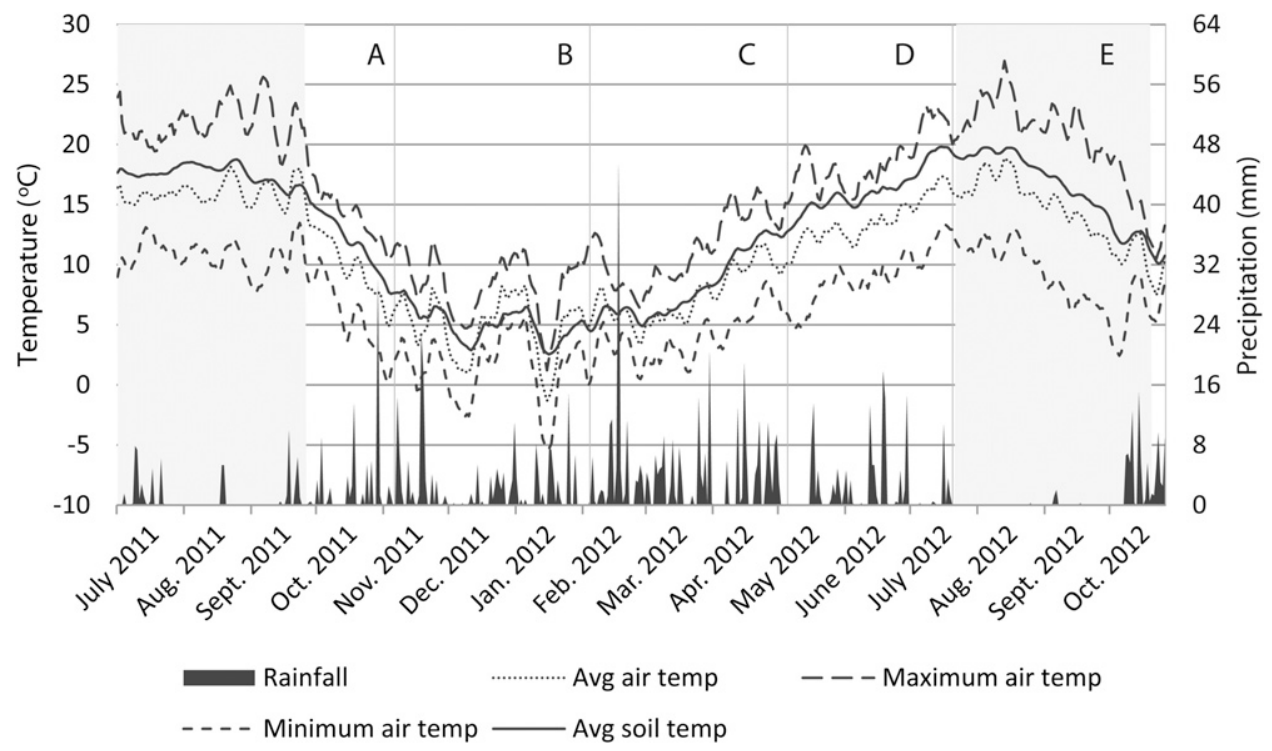

Fig. 1. Climate data during the study period from mulch laying in 2011 (5 July) until final soil sampling in 2012 (30 Oct.). Air temperature data presented are 7 -d averages. Shaded regions indicate 2011 and 2012 broccoli growing seasons. Vertical lines represent soil sampling on (A) 10 Nov. 2011, (B) 8 Feb., (C) 9 May, (D) 24 July, and (E) 30 Oct. 2012; 42, 132, 223, 299, and $397 \mathrm{~d}$, respectively, after mulch was incorporated into soil by tillage $(29 \mathrm{Sept} .2011) ;\left(1.8 \times{ }^{\circ} \mathrm{C}\right)+32={ }^{\circ} \mathrm{F}, 1 \mathrm{~mm}=0.0394 \mathrm{inch}$.

Table 2. Late-summer broccoli production dates and growing environment characteristics at Mount Vernon, WA, in 2011 and 2012. ${ }^{\mathrm{z}}$

\begin{tabular}{|c|c|c|}
\hline & 2011 & 2012 \\
\hline Mulch laid & 5 July & 26 July \\
\hline Broccoli transplanted & 6 July & 26 July \\
\hline Final broccoli harvest & 29 Sept. & 23 Oct. \\
\hline Growing degree days $\left(>5^{\circ} \mathrm{C}\right)^{\mathrm{y}}$ & 977 & 859 \\
\hline Avg daily maximum air temperature $\left({ }^{\circ} \mathrm{C}\right)^{y}$ & 21.8 & 20.5 \\
\hline Avg daily minimum air temperature $\left({ }^{\circ} \mathrm{C}\right)$ & 10.7 & 8.6 \\
\hline \multicolumn{3}{|l|}{ Avg soil temperature at 2 inches $(5.1 \mathrm{~cm})$ depth } \\
\hline Bare soil & 17.5 & 16.3 \\
\hline BioAgri $^{x}$ & 17.5 & $一^{\mathrm{w}}$ \\
\hline Crown $1^{x}$ & 17.7 & - \\
\hline SB-PLA- $11^{x}$ & 17.1 & - \\
\hline Avg daily solar radiation $\left(\mathrm{W} \cdot \mathrm{m}^{-2}\right)^{\mathrm{v}}$ & 205.1 & 184.2 \\
\hline Relative humidity $(\%)$ & 76.3 & 79.5 \\
\hline Avg wind speed $\left(\mathrm{km} \cdot \mathrm{h}^{-1}\right)^{\mathrm{v}}$ & 6.2 & 5.7 \\
\hline Total rainfall $(\mathrm{mm})^{\mathrm{v}}$ & 66.5 & 63.0 \\
\hline
\end{tabular}

${ }^{2}$ Environmental data collected from mulch laying until final harvest measured at Washington State University AgWeatherNet station located $1540 \mathrm{ft}(469.4 \mathrm{~m})$ from field plots, except as noted.

y

xSoil temperatures 2 inches beneath mulch products measured in one repetition during 2011; BioAgri ${ }^{\circledR} \mathrm{Ag}$-Film (BIOgroupUSA, Palm Harbor, FL), Crown 1 (Crown Films, Burlington, WA), and SB-PLA-11 (fabricated by Saxony Textiles, Chemnitz, Germany).

"No soil temperature measurements were recorded in 2012 due to equipment problems.

${ }^{\mathrm{v}} \mathrm{l} \mathrm{W} \cdot \mathrm{m}^{-2}=0.0929 \mathrm{~W} / \mathrm{ft}^{2}, \mathrm{l} \mathrm{km} \cdot \mathrm{h}^{-1}=0.6214 \mathrm{mph}, \mathrm{l} \mathrm{mm}=0.0394$ inch

season, except at 36 DAT (31 Aug.) when no differences were detected due to any of the mulch products. The AUMDC was calculated from PVD (Eq. [2]) over each growing season, and in 2011 it was greatest for Crown 1 , which was 4 times greater than for BioAgri and 25 times greater than for SB-PLA-11 $(P<0.0001)$. In 2012 , this trend was the same and AUMDC for Crown 1 was again 4 times greater than for BioAgri, but was 100 times greater than for $\mathrm{SB}$ PLA-11 $(P<0.0001)$.

Postincorporation image ANALYSIS. The total area of mulch fragments recovered postincorporation differed significantly due to mulch product $(P<0.0001)$ and sampling time $(P<0.0001)$; however, there were no differences due to soil treatment and no interactions were detected among mulch product, soil treatment, and sampling time $(P \geq 0.15)$. The percent mulch recovered, calculated as the total area of recovered mulch fragments minus the theoretical maximum area $\left(37.5\right.$ inch $\left.^{2}\right)$, was $41.3 \%$ for Crown 1 at the first sampling date (10 Nov. 2011) and declined steadily throughout the study until the final sampling date, $397 \mathrm{~d}$ after incorporation (30 Oct. 2012), when no mulch fragments were found (Figs. 3 and $4 \mathrm{~A}$ ). The percent mulch recovered for BioAgri was about equal to the theoretical maximum mulch area through $223 \mathrm{~d}$ after incorporation (9 May 2012), and thereafter declined to $34.6 \%$ by the final sample date. For SB-PLA-11, the average percent mulch recovered for the entire study period exceeded $100 \%$ of the theoretical maximum mulch area, indicating that more mulch was recovered from most soil samples than would have covered the soil surface above those samples initially. The average percent mulch recovered for all mulch products was $41.4 \%$ greater at 42 and 132 $\mathrm{d}$ after incorporation (10 Nov. 2011 and 8 Feb. 2012, respectively) than the percent mulch recovered at 299 and $397 \mathrm{~d}$ after incorporation (24 July and 30 Oct. 2012, respectively). At 223 d after incorporation (9 May 2012), the average percent mulch recovered was $11.3 \%$ greater than at $397 \mathrm{~d}$ after incorporation (30 Oct. 2012). 

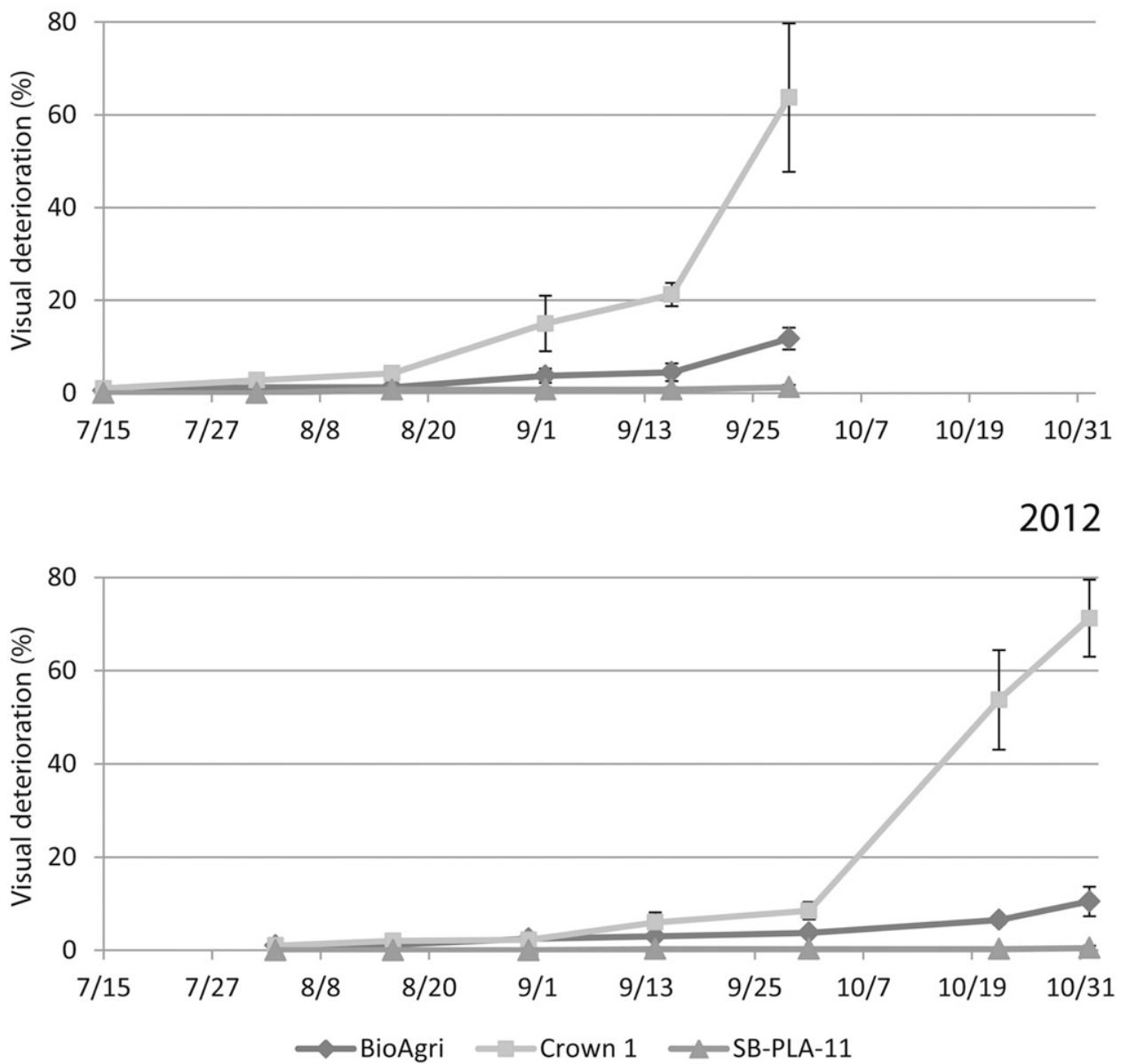

Fig. 2. Pre-tillage mulch deterioration evaluated as percent visual deterioration (PVD) during late-summer broccoli crops in 2011 and 2012 near Mount Vernon, WA. Statistically significant $(P \leq 0.02)$ differences between Crown 1 (Crown Films, Burlington, WA), BioAgri (BIOgroupUSA, Palm Harbor, FL), and SB-PLA-11 (fabricated by Saxony Textiles, Chemnitz, Germany) mulch treatments were detected for every assessment date in 2011 , and every date in 2012 except 1 Sept. $(P=0.07)$.

The average area of individual mulch fragments recovered postincorporation differed significantly due to mulch product $(P<0.0001)$ and time $(P<0.0001)$; however, there were no differences due to soil treatment and no interactions were detected among mulch product, soil treatment, and time $(P \geq 0.11)$. The average fragment area for Crown 1 samples throughout the study period was 7 times less than that for BioAgri and 37 times less than that for SB-PLA-11 (Figs. 3 and 4B). The average mulch fragment area for BioAgri samples was five times less than that for SBPLA-11. The average fragment area of all mulch products declined over time and was $18.6 \mathrm{~cm}^{2}$ at $42 \mathrm{~d}, 12.3$ $\mathrm{cm}^{2}$ at $132 \mathrm{~d}, 12.0 \mathrm{~cm}^{2}$ at $223 \mathrm{~d}$, $6.1 \mathrm{~cm}^{2}$ at $299 \mathrm{~d}$, and $4.6 \mathrm{~cm}^{2}$ at $397 \mathrm{~d}$ after incorporation. The average area of all mulch fragments decreased
$75 \%$ from the first to the last sample date.

The average number of mulch fragments recovered postincorporation differed significantly due to mulch product $(P<0.0001)$ and time $[P=0.0032$ (Figs. 3 and $4 \mathrm{C}$ ) ] but not due to soil treatment $(P=0.80)$, and there were significant product $\times$ time $(P<0.0001)$ and soil treatment $x$ time $(P=0.02)$ interactions detected. Therefore, the average number of mulch fragments per sample are presented separately by time (Table 3 ). Soil treatment did not affect the number of mulch fragments except at $132 \mathrm{~d}$ after incorporation $(8 \mathrm{Feb}$. 2012) when there were three times more fragments recovered from bare ground than from mulched subplots. The number of mulch fragments in each sample differed significantly by mulch product at each sampling time.
From 42 through $223 \mathrm{~d}$ after incorporation (10 Nov. 2011 to 9 May 2012), Crown 1 and BioAgri had, on average, five times more mulch fragments per soil sample than SBPLA-11. At 299 d after incorporation (24 July 2012), nearly five times more fragments of BioAgri were recovered than of Crown 1 and SBPLA-11. During the final soil sampling, $397 \mathrm{~d}$ after incorporation (30 Oct. 2012), BioAgri had two times more fragments than SB-PLA-11, and no fragments of Crown 1 were recovered. There was a significant interaction between mulch product and soil treatment at $132 \mathrm{~d}$ after incorporation $[8$ Feb. 2012 $(P=0.006)]$; however, there were no significant differences due to soil treatment when analyzed by mulch product at this sample date $(P>0.05)$. 


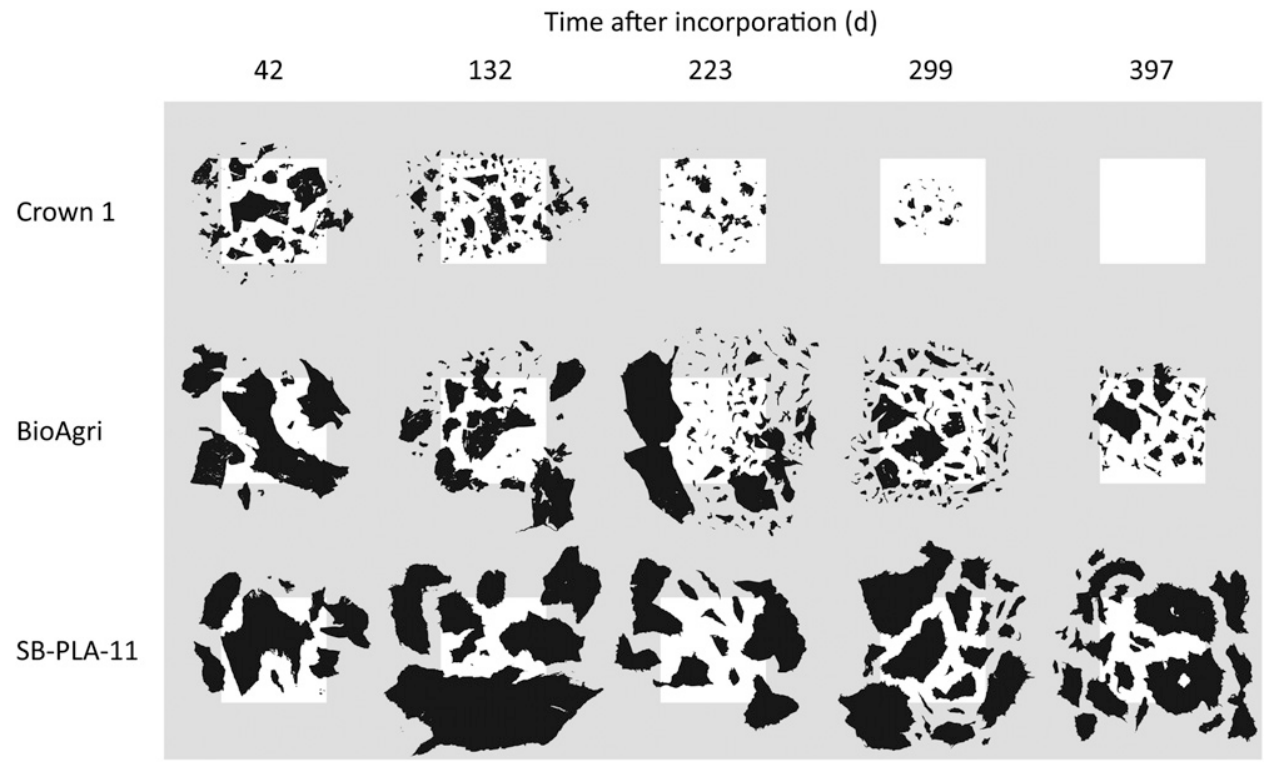

Fig. 3. Representative samples of Crown 1 (Crown Films, Burlington, WA), BioAgri (BIOgroupUSA, Palm Harbor, FL), and SB-PLA-11 (fabricated by Saxony Textiles, Chemnitz, Germany) mulch recovered from soil $\left[226.2 \mathrm{inch}^{3}\left(3706.75 \mathrm{~cm}^{3}\right)\right] 42$, $132,223,299$, and $397 \mathrm{~d}$ after mulch was incorporated by tillage. The white boxes represent the theoretical maximum mulch area $\left[37.5\right.$ inch $\left.^{2}\left(241.7 \mathrm{~cm}^{2}\right)\right]$ for each sample. $1 \mathrm{~cm}^{2}=0.1550$ inch $^{2}$.

\section{Discussion}

As measured by PVD, deterioration of the plastic films BioAgri and Crown 1 occurred more rapidly during the growing season than SB-PLA11. Holes began to appear in Crown 1 within 2 weeks of installation in both years. Within 4 to 6 weeks, Crown 1 had split down the center, where the film had been creased during manufacturing. Once the splits began to expand laterally, primarily due to wind action, PVD increased notably. However, by the time the center split opened, the plant canopy was sufficient to shade the exposed soil, thereby limiting weed growth. Like Crown 1, BioAgri also began to display holes 2 to 3 weeks after installation and BioAgri split down the center, typically between transplant holes, but not until 8 to 12 weeks after installation. It is important to note that when splits expanded, the mulch bunched at the edges of the split. Although this is not deterioration per se, this bunching formed creases which later split-effectively accelerating actual deterioration. All of the deterioration noted in SB-PLA-11 was due to damage at mulch edges from weeding tools. At no time during the 2011 and 2012 growing seasons did weeds become established in any of the mulched plots and manual weeding was not required. Despite varying degrees of deterioration among the mulch treatments, broccoli yield did not differ among mulches, and in 2012, yields in mulched plots were as much as $20 \%$ higher than bare ground (data not presented).

When mulch edges were excavated at the end of the 2011 growing season, Crown 1 was completely fragmented, BioAgri was partially fragmented and tore easily, and SB-PLA-11 was entirely intact. Crown $\mathrm{l}$ and BioAgri would be very difficult to remove from the field due to their fragmentation while SBPLA-11 would be relatively easy to retrieve. SB-PLA-11 could, potentially, be placed in a composting facility where it could be expected to biodegrade completely (Lunt, 2000).

Postincorporation mulch deterioration, as measured by total area of recovered fragments in a soil sample, was significantly different for the mulch products evaluated. At $42 \mathrm{~d}$ after incorporation, the total area of Crown 1 mulch fragments had decreased by more than $50 \%$ of the theoretical maximum mulch area per soil sample. The total area decreased at each subsequent sampling time, with no mulch found at the final sample date. The total fragment area of BioAgri samples did not substantively fall below the theoretical maximum mulch area until $299 \mathrm{~d}$ after incorporation, after which, the total area continually decreased, ending with only $35 \%$ of the theoretical maximum mulch area. However, SB-PLA-11 did not show a substantive decrease below the theoretical maximum mulch area. Rather, the final measure of SB-PLA-11 total mulch area was $125 \%$ of the theoretical maximum mulch area. Some samples of both BioAgri and SB-PLA-11 exceeded the theoretical maximum mulch area at one or more sampling times. BioAgri tended to stretch at fragment edges and SB-PLA-11 shredded at fragment edges, whereas Crown 1 had relatively clean fragment edges. Distortion of fragment edges for both BioAgri and SB-PLA-11 could have contributed to the recovery of more mulch than the theoretical maximum. Additionally, uneven distribution of mulch fragments during incorporation in the field is likely a source of error.

At the final preincorporation measurement date, mulch intactness for both Crown 1 and BioAgri was about equal to the percent mulch recovered on the first postincorporation sampling date. Before incorporation, Crown 1 and BioAgri were $36 \% \pm 8 \%$ and $88 \% \pm 1 \%$ intact, respectively, and the percent mulch recovered at the first sampling time were $41 \% \pm 10 \%$ and $119 \% \pm 34 \%$, respectively. Although post-tillage deterioration and PVD for BioAgri do not agree as closely as for Crown 1 , this 

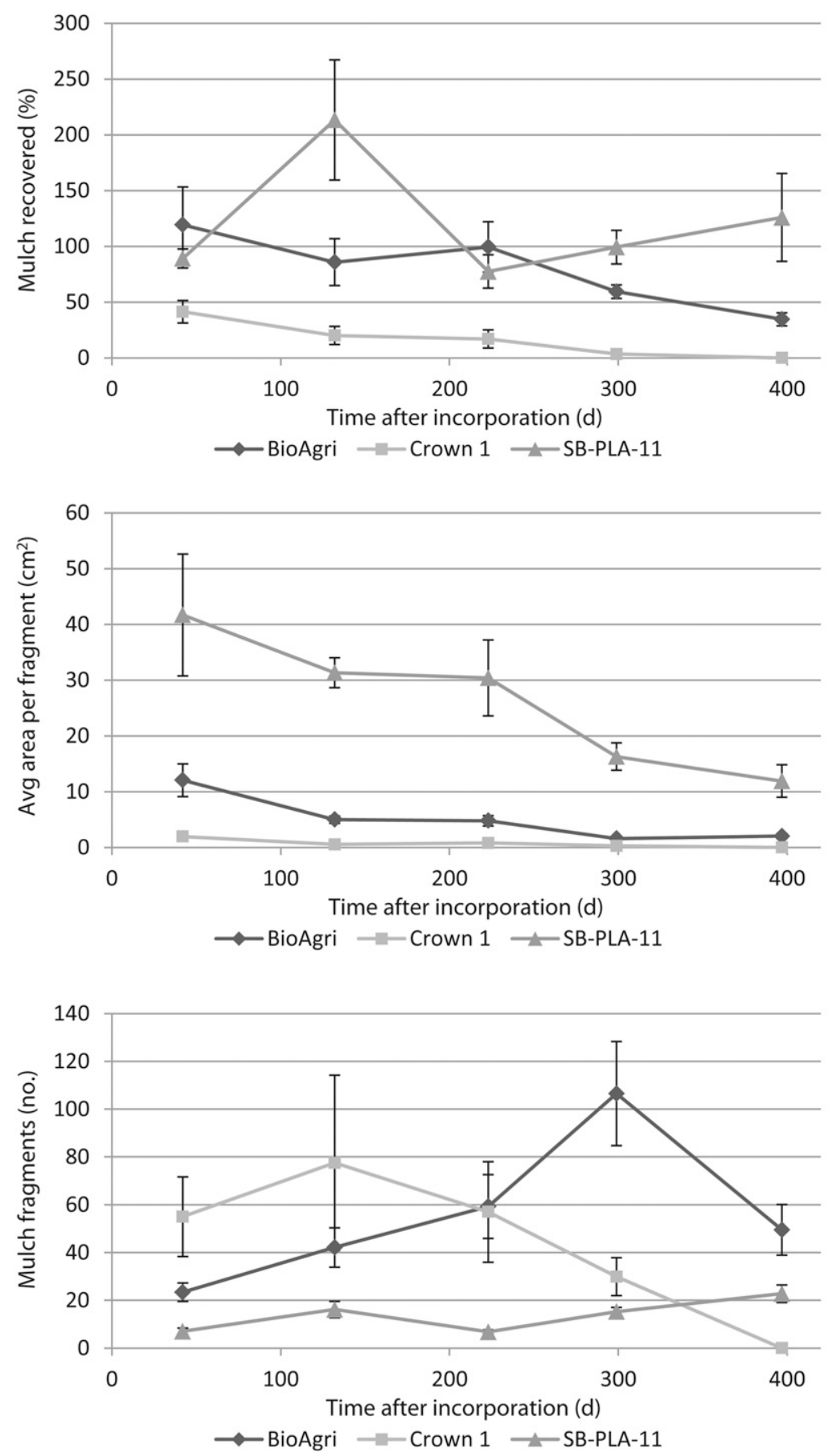

Fig. 4. (A) Postincorporation percent mulch recovered calculated as the total area of Crown 1 (Crown Films, Burlington, WA), BioAgri (BIOgroupUSA, Palm Harbor, FL), and SB-PLA-11 (fabricated by Saxony Textiles, Chemnitz, Germany) mulch recovered from soil samples $\left[226.2 \mathrm{inch}^{3}\left(3706.75 \mathrm{~cm}^{3}\right)\right]$ divided by the theoretical maximum mulch area $\left[37.5\right.$ inch $\left.^{2}\left(241.7 \mathrm{~cm}^{2}\right)\right]$ over 13 months after mulch was soil incorporated by tillage; (B) average area of mulch fragments decreased after soil incorporation for all materials evaluated; $(C)$ number of mulch fragments recovered from soil samples initially increased, then decreased as mulches fragment or biodegrade to microscopic sizes; $1 \mathrm{~cm}^{2}=0.1550 \mathrm{inch}^{2}$.

finding suggests that PVD may be a good indicator of deterioration, especially at higher levels of deterioration.

Both BioAgri and Crown 1 had an initial increase followed by a decrease in the number of mulch fragments in a soil sample, whereas the number of SB-PLA-11 fragments generally increased throughout the season. The increase in the number of mulch fragments indicates that the mulch continued to fragment postincorporation. The case for continued postincorporation fragmentation is further supported by the consistent decrease in the average area of mulch fragments for all the mulch products throughout the study. The number of fragments of Crown 1 and BioAgri peaked at 132 $\mathrm{d}$ after incorporation and $299 \mathrm{~d}$ after incorporation, respectively. The peak fragment counts corresponded to average fragment areas of 0.54 and 1.59 $\mathrm{cm}^{2}$, respectively. Subsequent fragment counts decreased while measurements of average fragment area remained substantively unchanged. This finding suggests that a threshold particle size may exist for each mulch material signaling accelerated degradation in the soil. It is likely that this accelerated degradation corresponds to biodegradation in the soil. Using the method described in ASTM 598803 (2003), César et al. (2009) found that smaller particles of a poly $(\varepsilon$ caprolactone)/starch blend biodegraded more rapidly than larger particles. This phenomenon is likely to be consistent for all biodegradable materials and warrants further investigation. However, because the biotic phase of biodegradation does not depend solely on particle sizes amenable to biological action but also on environmental conditions and microbial communities present in the soil (Krzan et al., 2006; Mergaert et al., 1993), it is likely that the threshold particle size for a mulch film will vary by location.

The difference between the number of mulch fragments recovered from mulched and bare ground subplots at $132 \mathrm{~d}$ after incorporation was not a treatment effect since the soil treatments were not applied until 301 $\mathrm{d}$ after incorporation (26 July 2012). Rather, the difference was likely due to uneven distribution of mulch fragments during incorporation.

Percent visual deterioration appears to be a reliable measure of the loss of functional integrity of biodegradable plastic mulch in the field. Though not a direct measure of degradation, PVD is a good visual indicator of deterioration, specifically, soil exposure in mulched beds. Growers in certified organic production could use PVD to evaluate the progress of biodegradable mulch deterioration throughout the growing season to help them decide whether 
Table 3. Number of mulch fragments recovered from bulked soil samples [226.2 inch $\left.^{3}\left(3706.75 \mathrm{~cm}^{3}\right)\right]$ collected from each subplot at five sampling times: 42 , $132,223,299$, and $397 \mathrm{~d}$ after mulch was incorporated into the soil by tillage on 29 Sept. $2011 .^{\mathrm{z}}$

\begin{tabular}{|c|c|c|c|c|c|}
\hline & \multicolumn{5}{|c|}{ Time after incorporation (d) } \\
\hline & $42^{y}$ & $132^{y}$ & $223^{x}$ & $299^{x}$ & $397^{x}$ \\
\hline \multicolumn{6}{|l|}{ Soil treatment } \\
\hline Bare ground & 21.6 & $66.9 \mathrm{a}^{\mathrm{w}}$ & 26.3 & 57.5 & 23.5 \\
\hline Mulched & 35.3 & $23.6 \mathrm{~b}$ & 55.7 & 43.6 & 24.7 \\
\hline$P$ value & 0.09 & 0.007 & 0.15 & 0.62 & 0.76 \\
\hline \multicolumn{6}{|l|}{ Mulch product ${ }^{\mathrm{v}}$} \\
\hline BioAgri ${ }^{\circledR}$ & $23.4 \mathrm{a}$ & $41.1 \mathrm{a}$ & $59.3 \mathrm{a}$ & $106.5 \mathrm{a}$ & $49.5 \mathrm{a}$ \\
\hline Crown 1 & $55.0 \mathrm{a}$ & $77.5 \mathrm{a}$ & $57.0 \mathrm{a}$ & $29.9 \mathrm{~b}$ & $0.0 \mathrm{c}$ \\
\hline SB-PLA-11 & $7.0 \mathrm{~b}$ & $16.1 \mathrm{~b}$ & $6.8 \mathrm{~b}$ & $15.3 \mathrm{~b}$ & $22.8 \mathrm{~b}$ \\
\hline$P$ value & 0.002 & 0.01 & 0.003 & 0.002 & $<0.0001$ \\
\hline
\end{tabular}

${ }^{\mathrm{z}}$ All means presented are nontransformed.

y Data were $\log _{10}$ transformed to meet the assumptions of normality for analysis of variance (ANOVA).

${ }^{x}$ No transformation satisfied the assumptions of normality for ANOVA; therefore, data were nonparametrically transformed using PROC RANK (SAS version 9.2 for Windows; SAS Institute, Cary, NC)

"Means within a column followed by the same letter are not significantly different $(P>0.05)$ as determined by Fisher's protected least significant difference test.

${ }$ BioAgri ${ }^{\circledR}$ Ag-Film (BIOgroupUSA, Palm Harbor, FL), Crown 1 (Crown Films, Burlington, WA), and SB-PLA11 (fabricated by Saxony Textiles, Chemnitz, Germany).

to till the mulch into the soil or remove the mulch to reduce accumulation of material that could jeopardize their organic certification.

Monitoring the total area of mulch fragments in a soil sample, by photographically analyzing sieved fragments, is a simple and potentially powerful tool for evaluating macroscale deterioration of biodegradable plastic mulch in the soil environment. However, the method is subject to significant variation among samples due to the distortion of fragment edges and uneven distribution of mulch fragments during incorporation. Quantifying the distortion of fragment edges and the effect on measurements of mulch deterioration would improve the efficacy of a photographic measure of post-tillage deterioration. To overcome the issue of uneven distribution, the number of samples evaluated should be increased.

The number of mulch fragments found in the soil after incorporation is not a direct measure of degradation. However, identifying the period during which fragment number in the soil is greatest may help determine the threshold fragment size for accelerated degradation of a mulch product in a particular soil and climate. This phenomenon could be explored further to advance the understanding of mulch degradation in the soil environment and could possibly be confirmed by evaluating the time to biodegrade mulch fragments of various sizes using ASTM 5988-03, the standard laboratory test methods for determining aerobic biodegradation in soil of plastic materials or residual plastic materials after composting (ASTM International, 2003) or similar laboratory methods.

Growers could use the photographic technique used in this study to monitor and demonstrate that biodegradable mulches incorporated into their soils are continuing to deteriorate and that macroscale accumulation of mulch fragments is not occurring. This method would require very little cost to the grower given that the ImageJ software is freely available on the internet and no specialized equipment is required.

Finally, two of the mulches evaluated in this study, BioAgri and Crown 1, deteriorated to a sufficient extent that they could meet the NOSB recommendation regarding biodegradation for certified organic production. Both mulches retained enough integrity throughout the growing season to inhibit weed growth. Thus, both mulches could be a suitable alternative to polyethylene mulch for broccoli production in the Pacific Northwest.

\section{Literature cited}

Anzalone, A., A. Cirujeda, J. Aibar, G. Pardo, and C. Zaragoza. 2010. Effect of biodegradable mulch materials on weed control in processing tomatoes. Weed Technol. 24:369-377.
Arméndariz, R., J.I. Macua, I. Lahoz, A. Santos, and S. Calvillo. 2006. The use of different plastic mulches on processing tomatoes. Acta Hort. 724:199-202.

ASTM International. 2003. ASTM D5988-03: Standard test methods for determining aerobic biodegradation in soil of plastic materials or residual plastic materials after composting. ASTM Intl., West Conshohocken, PA.

ASTM International. 2011a. ASTM D883-11: Standard terminology relating to plastics. ASTM Intl., West Conshohocken, PA.

ASTM International. 2011b. ASTM WK 29802. New specification for aerobically biodegradable plastics in soil environment. ASTM Intl., West Conshohocken, PA.

Briassoulis, D. 2006. Mechanical behaviour of biodegradable agricultural films under real field conditions. Polym. Degrad. Stabil. 91:1256-1272.

Briassoulis, D. 2007. Analysis of the mechanical and degradation performances of optimised agricultural biodegradable films. Polym. Degrad. Stabil. 92:11151132.

Calmon, A., S. Guillaume, V. BellonMaurel, P. Feuilloley, and F. Silvestre. 1999. Evaluation of material biodegradability in real conditions: Development of a burial test and an analysis methodology based on numerical vision. J. Polymers Environ. 7:157-166.

Candido, V., V. Miccolis, G. Gatta, S. Margiotta, and C. Manera. 2003. Innovative films for melon mulching in protected cultivation. Acta Hort. 614:379-386.

Cascone, G., A. D'Emilio, E. Buccellato, and R. Mazzarella. 2008. New biodegradable materials for greenhouse soil mulching. Acta Hort. 801:283-290.

César, M.E.F., P.D.S.C. Mariani, L.H. Innocentini-Mei, and E.J.B.N. Cardoso. 2009. Particle size and concentration of poly(3-caprolactone) and adipate modified starch blend on mineralization in soils with differing textures. Polym. Test. 20:680-687.

Cowan, J.S. 2013. The use of biodegradable mulch for tomato and broccoli production: Crop yield and quality, mulch deterioration, and growers' perceptions. PhD Diss., Washington State Univ., Pullman.

Garthe, J.W. and P.D. Kowal. 1993. Recycling used agricultural plastics. Penn State Fact Sheet C-8. 17 Sept. 2013. <http:// pubs.cas.psu.edu/freepubs/pdfs/C8.pdf>.

Jenni, S., D. Brault, and K.A. Stewart. 2004. Degradable mulch as an alternative 
for weed control in lettuce produced on organic soils. Acta Hort. 638:111-118.

Kapanen, A., E. Schettini, G. Vox, and M. Itävaara. 2008. Performance and environmental impact of biodegradable films in agriculture: A field study on protected cultivation. J. Polymers Environ. 16:109-122.

Kenward, M. and J. Roger. 1997. Small sample inference for fixed effects from restricted maximum likelihood. Biometrics 53:983-997.

Kijchavengkul, T., R. Auras, M. Rubino, M. Ngouajio, and R.T. Fernandez. 2008. Assessment of aliphatic-aromatic copolyester biodegradable mulch films. Part I: Field study. Chemosphere 71:942-953.

Kirk, R.E. 1982. Experimental design: Procedures for the behavioral sciences. 2nd ed. Brooks/Cole, Monterey, CA.

Klungland, M.W. and M. McArthur. 1989. Soil survey of Skagit County area, Washington. U.S. Dept. Agr., Soil Conservation Serv., Washington, DC.

Krzan, A., S. Hemjinda, S. Miertus, A. Corti, and E. Chiellini. 2006. Standardization and certification in the area of environmentally degradable plastics. Polym. Degrad. Stabil. 91:2819-2833.

Lamont, W.J. 2005. Plastics: Modifying the microclimate for the production of vegetable crops. HortTechnology $15: 477-481$

Lunt, J. 2000. Polylactic acid polymers for fibers and nonwovens. Intl. Fiber J. $15: 48-52$.

Martín-Closas, L., M.A. Bach, and A.M. Pelacho. 2008. Biodegradable mulching in an organic tomato production system. Acta Hort. 767:267-273.

Mergaert, J., A. Webb, C. Anderson, A. Wouters, and J. Swings. 1993. Microbial degradation of poly(3-hydroxybutyrate) and poly(3-hydroxybutyrate-co-3- hydroxyvalerate) in soils. Appl. Environ. Microbiol. 59:3233-3238.

Miles, C., C. Beus, A. Corbin, R. Wallace, A. Wszelaki, H. Saez, T. Walters, K. Leonas, M. Brodhagen, D. Hayes, and D. Inglis. 2009. Research and extension priorities to ensure adaptation of high tunnels and biodegradable plastic mulch in the United States. Proc. 35th Natl. Agr. Plastics Congr. p. 102-108.

Miles, C., R. Wallace, A. Wszelaki, J. Martin, J. Cowan, T. Walters, and D. Inglis. 2012. Deterioration of potentially biodegradable alternatives to black plastic mulch in three tomato production regions. HortScience 47:1270-1277.

Minuto, G., L. Pisi, F. Tinivella, C. Bruzzone, S. Guerrini, M. Versari, S. Pini, and M. Capurro. 2008. Weed control with biodegradable mulch in vegetable crops. Acta Hort. 801:291-297.

Moreno, M.M. and A. Moreno. 2008. Effect of different biodegradable and polyethylene mulches on soil properties and production in a tomato crop. Sci. Hort. 116:256-263.

Moreno, M.M., A. Moreno, and I. Mancebo. 2009. Comparison of different mulch materials in a tomato (Solanum lycopersicum L.) crop. Span. J. Agr. Res. 7:454-464.

National Climatic Data Center. 2013. Custom monthly summaries of GHCNDaily CSV. 7 Aug. 2013. <http://www. ncdc.noaa.gov/cdo-web>.

National Organic Standards Board. 2012. Formal recommendation: Petition to list biodegradable biobased mulch films on $\$ 205.601($ b)(2). 17 Sept. 2013. <http:// www.ams.usda.gov/AMSv1.0/getfile? $\mathrm{dDocName}=$ STELPRDC5101277> .

Ngouajio, M., R. Auras, R.T. Fernandez, M. Rubino, J.W. Counts, Jr., and T. Kijchavengkul. 2008. Field performance of aliphatic-aromatic copolyester biode- gradable mulch films in a fresh market tomato production system. HortTechnology 18:605-610.

Olsen, J.K. and R.K. Gounder. 2001. Alternatives to polyethylene mulch film: A field assessment of transported materials in capsicum (Capsicum annuum L.). Aust. J. Exp. Agr. 41:93-103.

Rangarajan, A. and B. Ingall. 2006. Biodegradable mulch product testing 2006. 17 Sept. 2013. <http://www.vegetables. cornell.edu/alt/Biodegradable\%20Mulch\% 20Product\%20Testing\%2020063.pdf>.

Rasband, W.S. 1997. ImageJ. 17 Sept. 2013. <http://rsb.info.nih.gov/ij>.

Saxton, A.M. 2010. DandA.sas: Design and analysis macro collection version 2.11. 17 Sept. 2013. <http://dawg.utk.edu/ glossary $/ . \% 5$ Csas $\% 5$ Cdanda212\%5Cdanda. sas>.

Scarascia-Mugnozza, G., E. Schettini, G. Vox, M. Malinconico, B. Immirzi, and S. Pagliara. 2006. Mechanical properties decay and morphological behaviour of biodegradable films for agricultural mulching in real scale experiment. Polym. Degrad. Stabil. 91:2801-2808.

Shogren, R.L. 2000. Biodegradable mulches from renewable resources. J. Sustain. Agr. 16:33-47.

Shogren, R.L. and R.C. Hochmuth. 2004. Field evaluation of watermelon grown on paper-polymerized vegetable oil mulches. HortScience 39:1588-1591.

Tocchetto, R.S., R.S. Benson, and M. Dever. 2001. Outdoor weathering evaluation of carbon-black-filled, biodegradable copolyester as substitute for traditionally used, carbon-black-filled, non-biodegradable, high-density polyethylene mulch films. J. Polymers Environ. 9:57-62.

U.S. Department of Agriculture. 2013. Web soil survey. 17 Sept. 2013. <http:// websoilsurvey.nrcs.usda.gov>. 